\title{
POCKET BOOK DIGITAL BERBASIS ETNOMATEMATIKA SEBAGAI BAHAN AJAR SEKOLAH MENENGAH PERTAMA
}

\author{
Ika Herawati ${ }^{1}$, Fredi Ganda Putra ${ }^{2}$, Rubhan Masykur ${ }^{3}$, Chairul Anwar ${ }^{4}$ \\ Universitas Islam Negeri Raden Intan Lampung, ikahera06@gmail.com ${ }^{1}$ \\ Universitas Islam Negeri Raden Intan Lampung, fredigandaputra@,radenintan.ac.id ${ }^{2}$ \\ Universitas Islam Negeri Raden Intan Lampung, rubhanmasykur@,radenintan.ac.id ${ }^{3}$ \\ Universitas Islam Negeri Raden Intan Lampung, chairul.anwar@radenintan.ac.id ${ }^{4}$ \\ Received : 3 April 2020, Revised : 15 April 2020, Accepted : 23 April 2020 \\ (C) Mathematics Education Unugiri 2020
}

\begin{abstract}
The purpose of this research is to know the development, response and effectiveness of learning using a digital pocket book characterized by Ethnomatematics for junior High School. Research and Development methods. Data Analysis techniques Research on the development of digital pocket books using 2 qualitative and quantitative analytical techniques. Data collection techniques are obtained via polls, interviews, documentation, and tests. The research Model with ADDIE is analysis, design, development, implementation, and Evaluation (evaluation), and assessment. Research conducted at SMPN 7 Metro. The results of this study with students ' responses from the use of digital pocket books characterized by ethnomatematics in small scale tests were obtained on average of 3.49 with "very attractive" criteria and large scale acquired on average of 3.64 With the criteria "very interesting" and the effectiveness of the use of digital pocket Books characterized Ethnomatematics applied in the learning process get a test effect size of 0.59 by medium category. This causes the digital Pocket book to be effective for use in the learning process.
\end{abstract}

Keywords: Pocket Book; Ethnomatics; Teaching materials

\begin{abstract}
Abstrak
Tujuan dari penelitian ini yaitu untuk mengetahui pengembangan, respon maupun efektivitas pembelajaran menggunakan pocket book digital bercirikan etnomatematika untuk sekolah menengah pertama. Metode penelitian yang digunakan (Research and Development). Teknik Analisis Data Penelitian terhadap pengembangan pocket book digital menggunakan 2 teknik analisis Kualitatif dan Kuantitatif. Teknik Pengumpulan Data diperoleh melalui angket, wawancara, dokumentasi, dan tes. Model penelitian dengan ADDIE yaitu analysis (analisis), design (perancangan), development (pengembangan), implementation (implementasi), dan evaluation (evaluasi). Penelitian dilakukan di SMPN 7 Metro. Adappun hasil penelitian ini dengan respon peserta didik dari penggunaan pocket book digital bercirikan etnomatematika dalam uji skala kecil diperoleh rata-rata sebesar 3,49 dengan kriteria "sangat menarik" dan skala besar diperoleh rata-rata sebesar 3,64 dengan kriteria "sangat menarik" Dan tingkat Keefektifan penggunaan pocket book digital bercirikan etnomatematika yang diterapkan dalam proses pembelajaran mendapatkan nilai uji effect size sebesar 0,59 dengan kategori sedang. Hal ini menyebabkan pocket book digital efektif untuk digunakan dalam proses pembelajaran.
\end{abstract}

Kata kunci: Pocket Book; Etnomatika; Bahan Ajar 


\section{Pendahuluan}

Di era globalisasi ilmu pengetahuan maupun teknologi berkembang sangat pesat [1], mengakibatkan perubahan khususnya dalam bidang pendidikan bukan hanya ilmu pengetahuan yang ingin diraih [2] [3] melainkan untuk mengembangkan karakter yang baik dan soft skill peserta didik [4] [5]. Pendidikan terdapat matematika yang sering dikatakan sebagai induk dari semua ilmu pengetahuan, karnanya sangat penting untuk dipelajari [6] [7]. Maka dari itu untuk mempelajari matematika penuh makna dan kesadaran terhadap suatu hal yang dilakukan, dipahami, atau tidak dipahami [8]. Bukan hanya mengenai pemahaman konsep atau prosedurnya saja, tetapi peserta didik harus memahami fakta, konsep, relasi, dan prosedur matematika untuk menyelesaikan persoalan matematika [9] [10] [11].

Selain itu untuk meningkatkan hasil belajar peserta didik perlu adanya inovasi pembelajaran [12] [13], seperti adanya inovasi media pembelajaran lebih menarik diantaranya pocket book [14] [15]. Karena pocket book bentuknya praktis untuk menunjang peserta didik dalam memahami materi [16] [17] dan sebagai alat bantu dalam memberikan informasi terkait materi pelajaran yang bersifat satu arah [18] sehingga [19] menumbuh kembangkan potensi peserta didik menjadi pembelajar mandiri [20] [19]. Supaya pembelajaran pun lebih bermakna etnomatematika pun cocok digunakan [21] dengan mengungkapkan realitas keterkaitan budaya lingkungan dan matematika dalam pembelajaran [22] [23]. Karena materi tersebut dikaitkan langsung dengan budaya lokal di masyarakat [24]. Sehingga sangatlah penting etnomatematika diimplementasikan dalam pembelajaran matematika supaya tertanamkan rasa cinta peserta didik terhadap budaya lokal tetap lestari di era globalisasi [25].

$\begin{array}{cccr}\text { Penelitian } & \text { pocket book bercirikan } \\ \text { etnomatematika } & \text { belum pernah diteliti }\end{array}$

sebelumnya, namun ada beberapa penelitian sebelumnya yang sejenis dengan implementasi etnomatematika tentang kerajinan kain tapis Lampung dan siger Lampung ke dalam pembelajaran matematika pada jenjang sekolah dasar [26]. Selain itu Penelitian pocket book [27] layak digunakan dan peserta didik lebih tertarik dan termotivasi dalam mengikuti proses pembelajaran [28] juga mengakatan berkategori Valid dan produk layak untuk hal sejenis. Penelitian lain juga di lakukan oleh [29]. Berdasarkan hal tersebut penulis akan membuat penelitian ini dengan tujuan mengetahui pengembangan, respon maupun efektivitas pembelajaran menggunakan pocket book digital bercirikan etnomatematika untuk sekolah menengah pertama.

\section{Metode Penelitian}

Metode penelitian yang digunakan yaitu (Research and Development). Teknik Analisis Data Penelitian terhadap pengembangan pocket book digital menggunakan 2 teknik analisis Kualitatif dan Kuantitatif. Teknik Pengumpulan Data diperoleh melalui angket, wawancara, dokumentasi, dan tes Instrumen Penelitian ini diantaranya Studi Pendahuluan, Instrumen Validasi Ahli, dan Instrumen Uji Coba Produk. Uji efektivitas memakai hasil pretest dan posttest yang diberikan lima soal esai pretest dan lima soal sai posttest. Model ADDIE terdiri dari lima tahapan yaitu analysis (analisis), design (perancangan), development (pengembangan), implementation (implementasi), dan evaluation (evaluasi). Tahap awal yang dilakukan peneliti ialah tahap analysis (analisis), pada tahap ini peneliti menganalisis kebutuhan guna mengetahui masalah yang terdapat di SMPN 7 Metro. Adapun model penelitian yang digunakan ditunjukan dengan bagan model ADDIE berikut ini. 


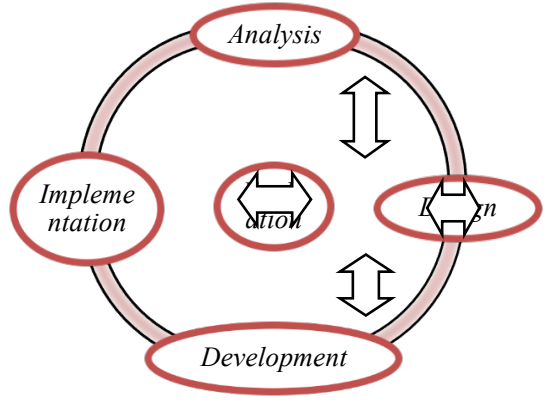

Gambar 1. Bagan Model ADDIE

Tahapan yang berdasarkan prosedur ADDIE yang dilakukan penelian ini yaitu analis bahan ajar yang sesuai dengan kompetensi yang didasarkan pada kebutuhan, kurikulum, dan karakteristik peserta didik sebagai sasaran. Penelitian awal di mulai dengan menyebar angket kepada peserta didik serta wawancara dengan pendidik matematika di sekolah, yang bertujuan mengetahui kendala apa saja yang terdapat disekolah yang berhubungan dengan pembelajaran matematika. Dilanjutkan dengan perancangan merancang pocket book digital yang sesuai dengan hasil dari tahapan analisis yang telah dilakukan sebelumnya. Seperti Proses dalam pembuatan pocket book dimulsi dengan Membuat peta konsep pocket book digital, membuat kerangka pocket book digital berupa garis besar pocket book dan penyusunan materi, membuat desain awal pocket book yang berciri etnomatematika sehingga lebih menarik, serta mengumpulkan referensi dan menyusun instrumen yang digunakan dalam proses penelitian.

Peneliti mengkonkretkan hasil perencanaan pada tahap design. Produk yang sudah dikonsep lalu dikembangkan dan divalidasi oleh ahli media dan ahli materi. Produk harus dikatakan layak dan valid oleh para ahli supaya diimpelemtasikan dalam pembelajaran. Setelah dinyatakan lulus Revisi sesuai dengan saran dan masukan dari para ahli mengenai kekurangan produk tersebut. Setelah produk dinyatakan layak kemudian dilanjutkan dengan proses produksi. maka pocket book diperbanyak dan diimplemtasikan saat pembelajaran di sekolah. Uji coba produk dilakukan guna mengetahui respon dari peserta didik meliputi kemenarikan dan kelayakan sehingga dapat memberikan masukan agar pocket book digital tersebut menjadi lebih baik.

\section{Hasil Penelitian}

Hasil validasi media tahap 2 penilaian nilai rata-rata aspek tipografi, kemudahan navigasi, keefektifan dan keefisienan, usabilitas, sederhana, warna, dan desain mengalami peningkatan yang cukup baik dan sudah berkriteria valid, berikut Grafik perbandingan nilai rata-rata hasil validasi media tahap 1 dan tahap 2 :

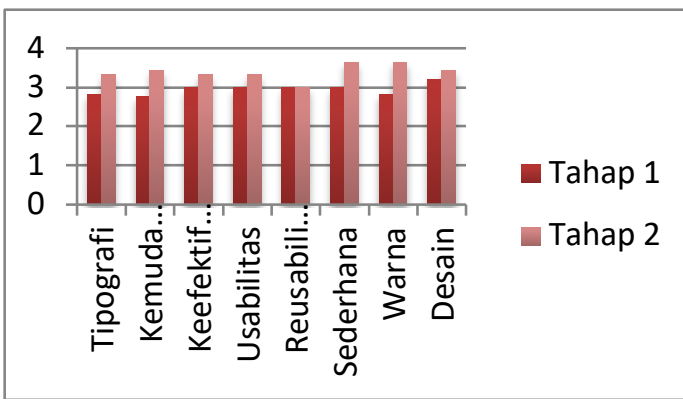

Gambar 2. Grafik Perbandingan Validasi Media Tahap 1 dan Tahap 2

Validasi media tahap 1 dan tahap 2. Berdasarkan penilaian aspek tipografi pada tahap 1 ke tahap 2 mengalami peningkatan sebesar 0,5 , penilaian aspek kemudahan navigasi tahap 1 ke tahap 2 mengalami peningkatan sebesar 0,67, penilaian aspek keefektifan dan keefisienan dan usabilitas mengalami peningkatan sebesar 0,33, penilaian aspek reabilitas pada tahap 1 dan tahap 2 sama yaitu 3, penilaian aspek sederhana pada tahap 1 dan tahap 2 mengalami peningkatan sebesar 0,66, penilaian aspek warna pada tahap 1 dan tahap 2 mengalami peningkatan sebesar 0,83 dan terakhir pada aspek desain mengalami peningkatan sebesar 0,22. Dapat disimpulkan dari hasil validasi ialah pocket bookdigital "valid digunakan tanpa revisi". 
Adapun beberapa perubahan pocket book digital sebelum dan sesudah revisi. Dengan Saran ataupun komentar dari ahli materi yaitu pada gambar kubus sebelum revisi tampak seperti balok sehingga perlu dirubah supaya tampak seperti gambar kubus.
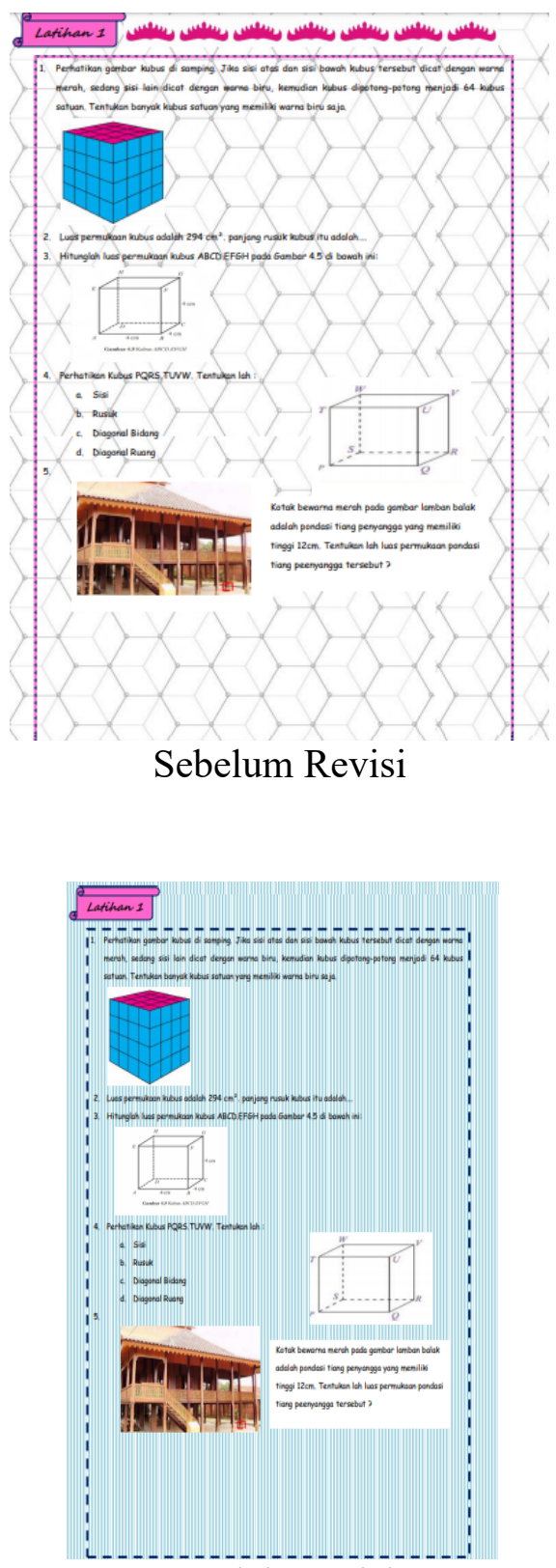

Setelah Revisi

Gambar 3. Perbaikan Gambar Kubus

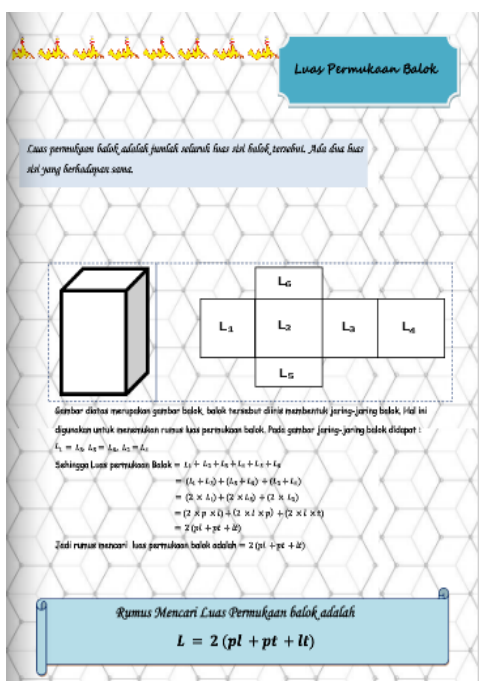

Sebelum Revisi

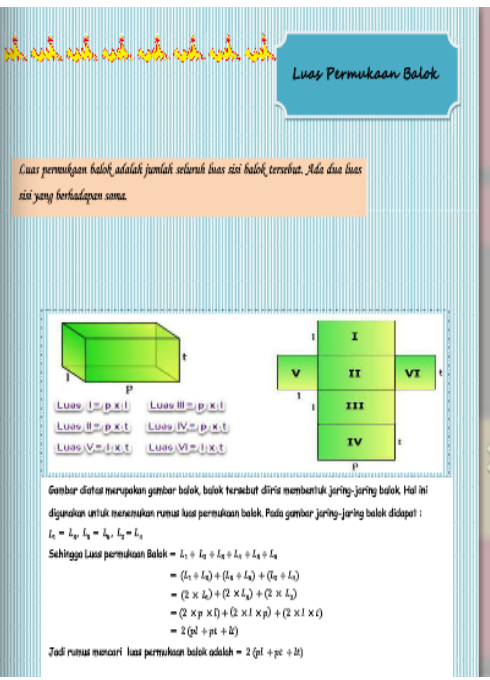

Setelah Revisi

Gambar 4. Perbaikan Gambar Jaring-jaring Balok 

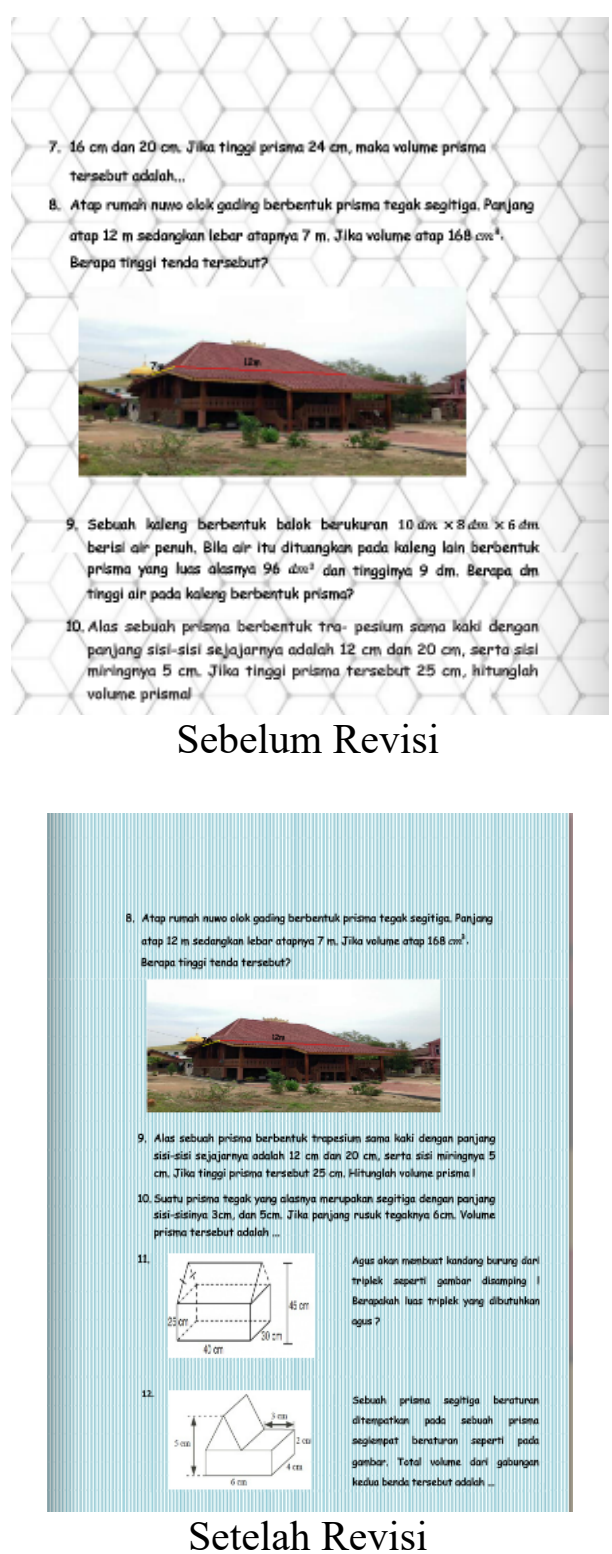

Gambar 5. Latihan Soal Bangun Ruang Sisi Datar Gabungan

Saran dan komentar lain yang diberikan validator ahli materi untuk perbaikan pocket book digital ialah seperti gambar di atas dengan menambahkan latihan soal bangun ruang sisi datar gabungan. Berdasarkan langkah-langkah validasi yang telah dilakukan penilaian skala besar didapat nilai rata-rata sebesar 3,64 dengan kriteria "sangat menarik", hal ini memperlihatkan bahwa pocket book digital yang dikembangkan oleh peneliti memiliki kriteria menarik sebagai media pembelajaran yang akan digunakan pada materi bangun ruang sisi datar. Berikut grafik perbandingan uji skala kecil dan skala besar :

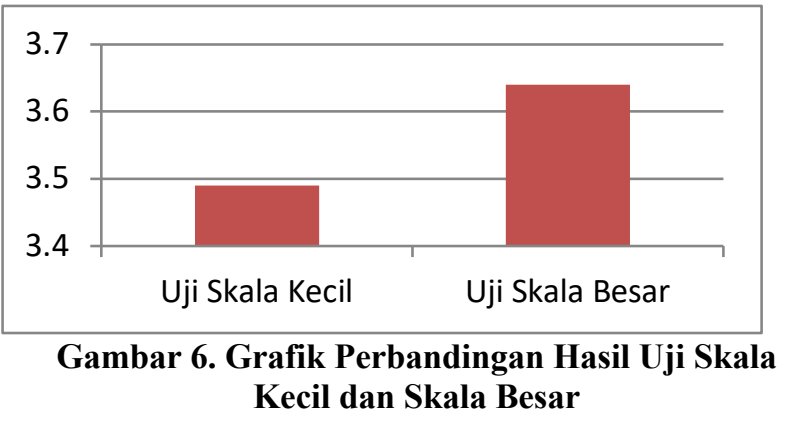

Uji kemenarikan produk yakni hasil dari pretest dan posttest digunakan dalam perhitungan perhitungan effect size dilihat pada Tabel 1:

Tabel 1. Hasil Perhitungan Effect Size

\begin{tabular}{ccccc}
\hline Kategori & N & $\begin{array}{c}\text { Rata- } \\
\text { rata }\end{array}$ & $\begin{array}{c}\text { Standar } \\
\text { Deviasi }\end{array}$ & $\begin{array}{c}\text { Effect } \\
\text { Size }\end{array}$ \\
\hline Pretest & 30 & 22,23 & 25,81 & \\
Posttest & 30 & 45,4 & 49,01 & 0,59 \\
\hline
\end{tabular}

Berdasarkan perolehan data pada Tabel 1 Rata-rata pretest dan posttest adalah 22,23 dan 45,4 serta standar deviasi pretest sebesar 25,81 , standar deviasi posttest sebesar 49,01 dan effect size sebesar 0,59. Sehingga dapat disimpulkan bahwa pocket book digital cukup efektif dan dapat digunakan dalam pembelajaran matematika materi bangun ruang sisi datar. Setalah itu prosedur tahapan terakhir dalam ADDIE yaitu evaluasi dengan menganalisis data hasil penelitian yang didapat dari analisis kevalidan media dan materi dari ahli serta angket respon peserta didik dan berhenti setelah hasil akhir dari pocket book digital mempunyai kriteria "sangat menarik" sehingga pocket book digital dapat digunakan selama pembelajaran.

Metode (Research and Development) yang digunakan bertujuan untuk mengembangkan produk berupa pocket book digital bercirikan etnomatematika untuk 
peserta didik sekolah menengah pertama, selain itu tujuan lainnya adalah mengetahui respon peserta didik dan keefektifan dari penggunaan pocket book digital yang dikembangkan pada proses pembelajaran. Setelah analisis kebutuhan dilanjutkan dengan analisis kurikulum untuk melihat kompetensi dasar dam indikator yang akan dicapai. Kurikulum yang digunakan dalam pembelajaran di SMP yakni Kurikulum 2013. Kemudian karakteristik peserta didik disesuaikan dengan isi materi dalam pocket book digital. selanjutnya dilakukan penyusunan desain pocket book digital, penyajian materi pocket book digital yang disesuaikan dengan kompetensi dasar, dan perencanaan instrumen berupa angket validasi dan respon peserta didik untuk mengevaluasi pocket book digital yang telah dibuat.

Setelah pocket book digital selesai dibuat selanjutnya dikonsultasikan kepada dosen pembimbing guna memperoleh saran perbaikan sebelum ke tahap validasi untuk mengetahui kekurangan dari pocket book digital dan masukan-masukan dari validator guna memperbaiki pocket book digital yang dikembangkan. Selain itu pocket book juga mempunyai kelebihan, Dibawah ini Kelebihan pocket book [30] antara lain :

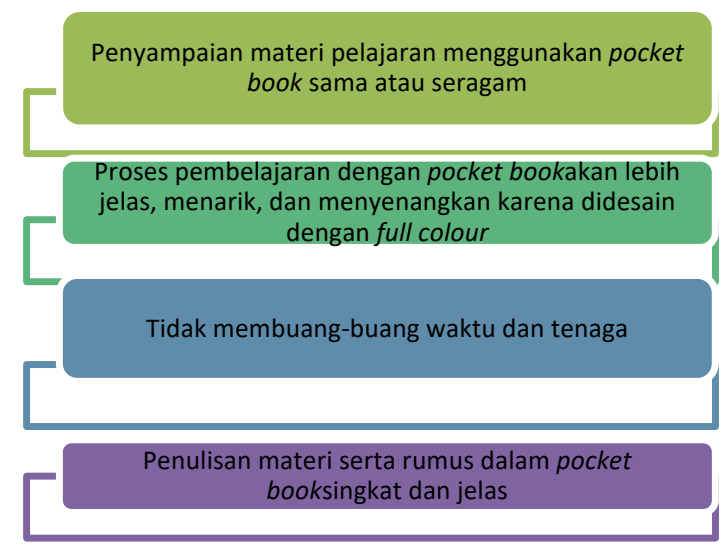

Adapun hasil penilaian validasi tahap 1 oleh ahli materi ialah aspek kesesuaian materi dengan $\mathrm{KI}$ dan KD didapat nilai rata-rata sebesar 3,16 dengan kriteria "cukup valid", aspek keakuratan materi didapat nilai rata-rata sebesar 2,88 dengan kriteria "cukup valid", aspek kemutakhiran materi didapat nilai ratarata sebesar 3 dengan kriteria "cukup valid", aspek mendorong keingintahuan didapat nilai rata-rata sebesar 3 dengan kriteria "cukup valid", aspek teknik penyajian didapat nilai rata-rata sebesar 3,33 dengan kriteria "valid", aspek keterlaksanaan didapat nilai rata-rata sebesar 3,10 dengan kriteria "cukup valid", dan aspek bahasa didapat nilai rata-rata sebesar 3 dengan kriteria "cukup valid".

Nilai rata-rata pada hasil penilaian validasi tahap 1 dan tahap 2 yang diberikan oleh validator media dan validator materi mengalami kenaikan. Pada hasil penilaian validasi tahap 2 pocket book digital dinyatakan valid untuk digunakan dalam proses pembelajaran.Tahap berikutnya adalah tahap implementation (implementasi), dimana pada tahap ini peneliti melakukan uji coba skala kecil, uji coba skala besar, dan uji efektivitas. Uji skala kecil dan uji skala besar guna mengetahui kemenarikan pocket book digital melalui pemberian angket respon peserta didik. Hasil olah data angket respon peserta didik pada uji coba skala kecil diikuti oleh 10 peserta didik yang dipilih secara acak, pocket book digital mendapatkan nilai rata-rata sebesar 3,49 dengan kriteria "sangat menarik". Sedangkan uji coba skala besar diikuti oleh 20 peserta didik, pocket book digital mendapatkan nilai rata-rata sebesar 3,64 dengan kriteria "sangat menarik". Dilihat dari nilai rata-rata pocket book digital pada uji skala kecil dan skala besar telah memenuhi aspek kemenarikan sehingga layak untuk diimpelemtasikan kepada peserta didik.

Uji efektivitas dilakukan guna mengetahui keefektifitasan pocket book digital dalam pembelajaran. Uji efektivitas ditinjau dari pretest dan posttest, hasil pretest dan posttest dianalisis menggunakan uji effect size. Hasil perhitungan nilai rata-rata pretest sebesar 22,23 hasil perhitungan nilai rata-rata posttest sebesar 45,4, standar deviasi pretest 
sebesar 25,81, standar deviasi posttest sebesar 45,4 dan effect size sebesar 0,59. Hal ini menunjukkan bahwa pocket book digital cukup efektif dalam proses pembelajaran.Tahap terakhir model ADDIE ialah evaluation (evaluasi) dimana tahap evaluasi dilakukan pada setiap tahap guna mengetahui kesalahan serta pembenaran pada setiap tahap. Berdasarkan hasil pengembangan yang dilakukan melalui 5 tahap diatas menghasilkan produk akhir yaitu pocket book digital yang sudah berkualifikasi layak, menarik, dan efektif dalam proses pembelajaran. Seperti Penelitian yang dilakukan oleh [17] bersumber pada penilaian oleh para ahli, pocket book terbukti layak dan mendapatkan respon baik dari peserta didik.

\section{Penutup}

\section{Kesimpulan}

Berdasarkan penelitian dan pembahasan yang telah dilakukan oleh peneliti, didapatkan keseimpulan bahwa Penelitian ini menghasilkan suatu produk yaitu pocket book digital bercirikan etnomatematika untuk peserta didik sekolah menengah pertama. Sedangkan Respon peserta didik dari penggunaan pocket book digital bercirikan etnomatematika dalam uji skala kecil diperoleh rata-rata sebesar 3,49 dengan kriteria "sangat menarik" dan skala besar diperoleh rata-rata sebesar 3,64 dengan kriteria "sangat menarik". Dengan tingkat Keefektifan penggunaan pocket book digital bercirikan etnomatematika yang diterapkan dalam proses pembelajaran mendapatkan nilai uji effect size sebesar 0,59 dengan kategori sedang. Hal ini menyebabkan pocket book digital efektif untuk digunakan dalam proses pembelajaran.

\section{Saran}

Adapun terdapat beberapa saran diharapkan kepada peneliti lain produk yang akan datang dapat menggunakan materi yang lebih luas. sehingga pengembangan pocket book digital bercirikan etnomatematika selanjutnya diharapkan lebih baik lagi. Untuk penelitian selanjutnya diharapkan pocket book digital bercirikan etnomatematika dapat diimplementasikan dalam skala yang lebih luas supaya tingkat keefektifannya semakin baik. Sehingga penelitian ini dapat dijadikan sebagai rujukan penelitian lanjutan.

\section{Referensi}

[1] HASANAH, U. N., Thahir, A., Komaruddin, K., \& Rahmahwaty, R. (t.t.). MURDER Learning and Self Efficacy Models: Impact on Mathematical Reflective Thingking Ability. Journal for the Education of Gifted Young Scientists, 7(4), 1123-1135.

[2] Fazlurrahman, M. (2018). Modernisasi Pendidikan Islam: Gagasan Alternatif Fazlur Rahman. TA'LIM: Jurnal Studi Pendidikan Islam, 1(1), 73-89.

[3] Latief, I. N. A. (2016). Model Respon Pendidikan Dalam Perubahan Sosial. Jurnal TadriS, 8(2), 97-112.

[4] Bahri, S. (2015). Implementasi pendidikan karakter dalam mengatasi krisis moral di sekolah. Ta'allum: Jurnal Pendidikan Islam, 3(1), 57-76.

[5] Firdaus, F. (2017). Urgensi Soft Skills Dan Character Building Bagi Mahasiswa. Jurnal Tapis: Jurnal Teropong Aspirasi Politik Islam, 13(1), 60-73.

[6] Karyanti, K., \& Komarudin, K. (2017). Pengaruh model pembelajaran kumon terhadap pemahaman matematis ditinjau dari gaya kognitif peserta didik pada mata pelajaran matematika kelas viii smp negeri satu atap 4 pesawaran. Prosiding Seminar Nasional Matematika dan Pendidikan Matematika, 1, 89-94.

[7] Maskur, R., Nofrizal, N., \& Syazali, M. (2017). Pengembangan Media Pembelajaran Matematika dengan Macromedia Flash. Al-Jabar: Jurnal Pendidikan Matematika, 8(2), 177-186. 
[8] Siagian, R. E. F., \& Nurfitriyanti, M. (2015). Metode pembelajaran inquiry dan pengaruhnya terhadap hasil belajar matematika ditinjau dari kreativitas belajar. Formatif: Jurnal Ilmiah Pendidikan MIPA, 2(1).

[9] Rakhmawati, R. (2016). Aktivitas Matematika Berbasis Budaya pada Masyarakat Lampung. Al-Jabar: Jurnal Pendidikan Matematika, 7(2), 221-230.

[10] Ramdani, Y. (2012). Pengembangan instrumen dan bahan ajar untuk meningkatkan kemampuan komunikasi, penalaran, dan koneksi matematis dalam konsep integral. Jurnal Penelitian Pendidikan, 13(1), 44-52.

[11] Sari, R. H. N. (2015). Literasi Matematika: Apa, Mengapa, dan Bagaimana. Seminar Nasional Matematika dan Pendidikan Matematika $U N Y, 8$.

[12] Juniati, N. W., \& Widiana, I. W. (2017). Penerapan Model Pembelajaran Inkuiri Untuk Meningkatkan Hasil Belajar IPA. Jurnal Ilmiah Sekolah Dasar, 1(1), 2029.

[13] Situmorang, M. (2014). Pengembangan buku ajar kimia Sma melalui inovasi pembelajaran dan integrasi pendidikan karakter untuk meningkatkan hasil belajar siswa. Prosiding SEMIRATA 2013, 1(1).

[14] Rosyid Eko Robiyanto, Z. (2019). Pengembangan Mobile Learning Pocket Book Android Untuk Melatihkan Kemampuan Literasi Pada Materi Gelombang Mekanik. Inovasi Pendidikan Fisika, 8(3).

[15] Satrianingsih, C. J. P., Haryani, S., \& Dewi, N. R. (2017). The Model Pembelajaran Berbasis Masalah Berbantuan Science Pocket Book untuk Meningkatkan Kemampuan Kognitif dan Sikap Terhadap Sains. Journal of Innovative Science Education, 6(2), 273281.
[16] Khumaidi, A., \& Sucahyo, I. (2018). Pengembangan mobile pocket book fisika sebagai media pembelajaran berbasis android pada materi momentum dan impuls. Inovasi Pendidikan Fisika, 7(2).

[17] Laksita, S. V., Supurwoko, S., \& Budiawanti, S. (2013). Pengembangan Media Pembelajaran FIsikaDalam Bentuk Pocket Book pada Materi Alat Optik Serta Suhu dan Kalor Untuk Kelas X SMA. Jurnal Materi dan Pembelajaran Fisika, 3(1).

[18] Pane, A., \& Dasopang, M. D. (2017). Belajar dan pembelajaran. Fitrah: Jurnal Kajian Ilmu-ilmu Keislaman, 3(2), 333352.

[19] Maryani, E., \& Syamsudin, H. (2009). Pengembangan Program Pembelajaran IPS untuk meningkatkan kompetensi Keterampilan sosial. Jurnal Penelitian, 9(1).

[20] Agustiana, N., Supriadi, N., \& Komarudin, K. (2019). Meningkatkan Kemampuan Penalaran Matematis dengan Penerapan Pendekatan Bridging Analogy Ditinjau dari Self-Efficacy. Inovasi Pembangunan: Jurnal Kelitbangan, 7(1), 61-61.

[21] Prabawa, E. A., \& Zaenuri, Z. (2017). Analisis Kemampuan Pemecahan Masalah Ditinjau Dari Gaya Kognitif Siswa Pada Model Project Based Learning Bernuansa Etnomatematika. Unnes Journal of Mathematics Education Research, 6(1), 120-129.

[22] Martyanti, A., \& Suhartini, S. (2018). Etnomatematika: Menumbuhkan Kemampuan Berpikir Kritis Melalui Budaya Dan Matematika. IndoMath: Indonesia Mathematics Education, 1(1), 35-41.

[23] Putri, L. I. (2017). Eksplorasi etnomatematika kesenian rebana sebagai sumber belajar matematika pada jenjang MI. Jurnal Ilmiah Pendidikan Dasar, 4(1). 
[24] Hermoyo, R. P., \& Suher, M. (2017). Peranan Budaya Lokal Dalam Materi Ajar Bahasa Indonesia Bagi Penutur Asing (BIPA). ELSE (Elementary School Education Journal): Jurnal Pendidikan dan Pembelajaran Sekolah Dasar, 1(2b).

[25] Nurafni, A., Pujiastuti, H., \& Mutaqin, A. (2020). Pengembangan Bahan Ajar Trigonometri Berbasis Kearifan Lokal. Journal of Medives: Journal of Mathematics Education IKIP Veteran Semarang, 4(1), 71-80.

[26] Putra, R. W. Y., \& Indriani, P. (2017). Implementasi Etnomatematika Berbasis Budaya Lokal dalam Pembelajaran Matematika pada Jenjang Sekolah Dasar. NUMERICAL: Jurnal Matematika Dan Pendidikan Matematika, 9-14.

[27] Asyhari, A., \& Silvia, H. (2016). Pengembangan Media Pembelajaran Berupa Buletin dalam Bentuk Buku Saku untuk Pembelajran IPA Terpadu. Jurnal Ilmiah Pendidikan Fisika Al-Biruni, 5(1), $1-13$.
[28] Agnasari, R. (2019). Pengembangan Pocket Book Digital Berbasis Scaffolding Materi Fungsi Pada Kelas X SMA Tunas Bangsa Lampung Selatan. UIN Raden Intan Lampung.

[29] FARINA PUTRI, Y. (2017). Pengembangan Aplikasi Buku Saku Berbasis Android Sebagai Media Pembelajaran Hukum Kesehatan di Akademi Farmasi Surabaya. IT-Edu: Jurnal Information Technology and Education, 2(02).

[30] Mukminah, M., Sukroyanti, B. A., \& Fuaddunazmi, M. (2015). Pengaruh Penggunaan Pocket Book Siswa Dengan Teknik Evaluasi Media Puzzle Ceria Terhadap Aktivitas Dan Hasil Belajar. Lensa: Jurnal Kependidikan Fisika, 3(2), 288-293. 